\title{
Obituary
}

\section{Andrew Batavia}

Spinal Cord (2003) 41, 573. doi:10.1038/sj.sc.3101503

Andrew Batavia, the quadriplegic Miami Beach lawyer who helped write the landmark Americans with Disabilities Act (ADA) and crusaded for legalizing doctor-assisted suicide, died Monday at the Jackson Memorial Hospital in Miami. He was 45. His wife, Cheryl Nicholson Batavia, said he had been suffering complications from a chronic urinary tract infection and had been hospitalized twice in the past month. Batavia was an associate professor of public-health policy at Florida International University and a former partner at the Miami law firm of McDermott, Will \& Emery. He had been in a wheelchair since he was injured in a car wreck when he was 16 in Yonkers, NY, USA. From the mid-1980s to the early 1990s, he worked in Washington, where he helped write the ADA Regulations in 1989. He was a special assistant to Attorney General Richard Thornburgh in the first Bush administration, associate director of the White House Domestic Policy Council and executive director of the National Council on Disability. He was a White House Fellow and later served as Arizona Sen. John McCain's legislative assistant. A prolific writer on disability and right-todie issues, he briefly wrote a disability issues column for The Miami Herald in 1997 after moving to South Florida because he liked the warmer weather. Batavia filed a Friend of the Court brief with the US Supreme Court in 1997, favoring a terminally ill person's right to choose his or her time of death, a position vigorously opposed by many other disability activists who feared it would lead to the abuse of disabled people's rights. Batavia spent a year in rehabilitation following the car crash in which he was a passenger, and returned to Lincoln High School in Yonkers, becoming class president. He graduated from the University of California at Riverside and Harvard Law School and earned a master's degree in health services research at Stanford University Medical School. 'If I have one sentence to say about him it would be: 'Give me a challenge, because I love challenges,' said his mother, Renee Batavia of Boynton Beach. 'That's how he spent his whole life. I never regarded him as disabled because he didn't regard himself as disabled and never used it to get anything for himself. In 1996, Cheryl, and Drew, as he was known, adopted two Russian children: Joe, now 12, and Katerina, now 11. Drew feared they would be denied the adoption because of his condition, so Cheryl travelled alone to an orphanage in Ekaterinburg, near Siberia.

He recently declared a 'new joy initiative' for his family, said Cheryl, a sixth-grade teacher at Florida International Academy. 'Negativity would not be tolerated. It was sort of annoying, but I found that he was right. He never took anything for granted.'

Batavia is also survived by his father, Gabe; brother, Mitch Batavia of New York; and sister, Donna of Hoboken, New Jersey; and TJ and Ellen Maher of North Miami Beach.

EJ Brecher Miami, FL, USA 